\title{
The Public's Evolution from News Reader to News Gatherer: An Analysis of the First Amendment Right to Videorecord Police
}

\author{
Ashley Billam*
}

\section{INTRODUCTION}

"That Men ought to speak well of their Governours is true, while their Governours deserve to be well spoken of; but to do public Mischief, without hearing of it, is only the Prerogative and Felicity of Tyranny: A free People will be shewing that they are so, by their Freedom of Speech.

The Administration of Government, is nothing else but the Attendance of the Trustees of the People upon the Interest and Affairs of the People: And as it is the Part and Business of the People, for whose Sake alone all public Matters are, or ought to be transacted, to see whether they be well or ill transacted; so it is the Interest, and ought to be the Ambition, of all honest Magistrates, to have their Deeds openly examined, and publicly scann'd."

Thomas Gordon, Silence Dogood No. $8^{I}$

On April 4, 2015, Officer Michael Slager, a white man, pulled over Walter Scott, a black man, for a broken brake light. ${ }^{2}$ Scott ran from the vehicle and Officer Slager pursued. ${ }^{3}$ At some point during the chase, Scott and Slager struggled and Scott broke free. ${ }^{4}$ As Scott ran away,

* J.D. Candidate, 2018, University of Kansas School of Law. I extend my deepest thanks to Professor Mike Kautsch for his invaluable insights. I would also like to thank Mathew Petersen, Mackenzie Sheehy, and the staff of the University of Kansas Law Review for their careful review of this Comment. Most of all, I thank my husband for his unfailing love, support, and encouragement throughout this process.

1. ACLU of Ill. v. Alvarez, 679 F.3d 583, 599 (7th Cir. 2012) (quoting Thomas Gordon, Silence Dogood No. 8, The New-England Courant (Boston), July 9, 1722, reprinted in 1 The Papers of Benjamin Franklin 28 (Leonard W. Labaree et al. eds., 1959)).

2. Catherine E. Shoichet, Video Could Be Key as Ex-Cop Goes on Trial in Walter Scott Killing, CNN (Oct. 31, 2016, 11:48 AM), http://www.cnn.com/2016/10/31/us/michael-slager-trialnorth-charleston/.

3. Michael Martinez, South Carolina Cop Shoots Unarmed Man: A Timeline, CNN (Apr. 9, 2015, 10:40 AM), http://www.cnn.com/2015/04/08/us/south-carolina-cop-shoots-black-mantimeline/.

4. Id. 
Slager shot Scott four times in the back. ${ }^{5}$ Immediately following the shooting, Slager claimed the two had struggled over his Taser. Slager said Scott had attempted to use the Taser on him, and he had resorted to his gun. ${ }^{6}$ The police department recounted Slager's version of events to the public. ${ }^{7}$ But then a bystander with a video came forward. ${ }^{8}$ Feidin Santana had captured the struggle, the shooting, and the immediate aftermath on his cell phone as he walked to work. ${ }^{9}$ The video showed Officer Slager was not in danger when he fired his gun-instead, Slager fatally shot Scott as he ran away. ${ }^{10}$ The video went viral. ${ }^{11}$ When presented with the video evidence, officials changed course and charged Slager with murder. ${ }^{12}$ Without the video it is unlikely that Slager's superiors or the public would have learned the truth and therefore it is unlikely that Slager would have been charged.

This and other police shootings caught on video have sparked a national conversation about police procedures, particularly procedures related to race and the use of force. As more people attempt to record the police, questions arise about whether the public has a right to videorecord on-duty police officers.

Most of the courts presented with the question have found that the First Amendment protects the public's right to videorecord police. ${ }^{13}$ The First, Third, Fifth, and Eleventh Circuits have now found in favor of First Amendment protection. ${ }^{14}$ Many more courts are likely to address this question in the future. This Comment examines the various ways courts

5. Id.

6. Michael E. Miller, Lindsey Bever, and Sarah Kaplan, How a Cellphone Video Led to Murder Charges Against a Cop in North Charleston, S.C., WASH. POST (Apr. 8, 2015), https://www.washingtonpost.com/news/morning-mix/wp/2015/04/08/how-a-cell-phone-video-ledto-murder-charges-against-a-cop-in-north-charleston-s-c/.

7. $I d$.

8. Id.

9. Harriet McLeod, Reuters, Jury Watches Cell Phone Video in the Case of a White South Carolina Officer Who Shot a Black Man, BuS. INSIDER (Nov. 4, 2016, 6:39 PM), http://www.businessinsider.com/jury-watches-cell-phone-video-in-the-case-of-a-white-southcarolina-officer-who-shot-a-black-man-2016-11.

10. Alan Blinder, Mistrial for South Carolina Officer Who Shot Walter Scott, (Dec. 5, 2016), N.Y. TIMES, https://www.nytimes.com/2016/12/05/us/walter-scott-michael-slager-northcharleston.html?_r=0.

11. Id.

12. Miller et al., supra note 6. The first trial ended in a mistrial, with prosecutors saying they intended to try Slager again. Blinder, supra note 10.

13. See, e.g., Glik v. Cunniffe, 655 F.3d 78 (1st Cir. 2011); Smith v. City of Cumming, 212 F.3d 1332 (11th Cir. 2000); Robinson v. Fetterman, 378 F. Supp. 2d 534 (E.D. Pa. 2005).

14. Fields v. City of Philadelphia, 862 F.3d 353 (3d Cir. 2017); Turner v. Lieutenant Driver, 848 F.3d 678 (5th Cir. 2017); Glik, 655 F.3d at 78; Smith, 212 F.3d at 1332. 
have analyzed whether the First Amendment protects citizens who videorecord police and proposes a framework that would provide greater stability in this area of law.

Most courts faced with this issue have focused on whether the person videorecording was engaged in an activity that was an exercise of freedom of speech. ${ }^{15}$ Though videographers are not literally speaking, courts have found that they may qualify for First Amendment protection when recording police. This may be true either because videographers are gathering information as an antecedent to speech or because they are engaged in expressive conduct. ${ }^{16}$ With these two types of protected speech in mind, courts condition First Amendment protection on finding facts that indicate the activity was an antecedent to speech or expressive conduct. This approach is reasonable in theory, but in practice it fosters viewpoint discrimination and provides journalists with more protection than the public.

When police object to or interfere with videorecoding by journalists, courts tend to grant journalists protection under the Press Clause ${ }^{17}$ of the First Amendment. However, when police object to or interfere with videorecoding by citizens, courts apply various Speech Clause ${ }^{18}$ approaches, which produce inconsistent and confusing results. This Comment argues that courts should correct the disparity between journalists and citizens by adopting a rebuttable presumption that citizens intend to publish video they take of police.

Courts analyzing this issue should consider the original purpose of the First Amendment, Supreme Court precedent, and the public interest. The original purpose of the First Amendment was to protect the forum for discussion of issues in the public interest. ${ }^{19}$ This protection applied to anyone who used the printing press to publish her thoughts and ideas. ${ }^{20}$ Courts typically presume journalists intend to gather news and publish in the public interest. When deciding whether a citizen's expressive freedom is protected, on the other hand, courts do not assume an intent to

15. See, e.g., ACLU of Ill. v. Alvarez, 679 F.3d 583, 596 (7th Cir. 2012); Fields v. City of Philadelphia, 166 F. Supp. 3d 528, 533-34 (E.D. Pa. 2016), rev'd, 862 F.3d 353 (3d Cir. 2017); Pluma v. City of New York, No. 13 Civ.2017(LAP), 2015 WL 1623828, at *7 (S.D.N.Y. 2015); Robinson, 378 F. Supp. 2d at 541.

16. See, e.g., Alvarez, 679 F.3d at 595-96; Pomykacz v. Borough of W. Wildwood, 438 F. Supp. 2d 504, 512-13, 513 n.14 (D.N.J. 2006).

17. See discussion infra Section II.B.1.

18. See discussion infra Section II.A.1.

19. See Alvarez, 679 F.3d at 597.

20. Eugene Volokh, Freedom for the Press as an Industry, or for the Press as a Technology? From the Framing to Today, 160 U. PA. L. REV. 459, 462-63 (2012). 
publish and therefore some courts limit protection. This disparity is counter to extensive precedent holding that the press does not enjoy greater rights under the First Amendment than average citizens. ${ }^{21}$ When courts fail to consider the original purpose of the Press and Speech Clauses they contribute to this disparity. ${ }^{22}$ Shifting the analysis to provide a limited rebuttable presumption that citizens who videorecord police intend to publish or speak would solve these problems.

This Comment begins in Part II with discussion of the original purpose and meaning of "freedom of the press" and "freedom of speech," as well as the tests that have developed under each clause and how those tests have been applied to the analysis of First Amendment protection for citizens videorecording police. Particular emphasis is given to the differences in the way the press and the public are treated. Part III argues that not only are speech and expressive conduct analyses ill-suited to the act of citizens videorecording police, applying these analyses causes courts to treat journalists more favorably than the public in contradiction of Supreme Court precedent. Finally, Part IV concludes with a summary of the approaches to analyzing protection for citizens who videorecord police and an argument for a presumption that citizens who videorecord police intend to publish the video.

\section{BACKGROUND}

The First Amendment was added to the United States Constitution in 1791. ${ }^{23}$ Much has changed in the last 226 years. The understanding of the words "speech" and "press" have evolved. Major advancements in technology have been made. And, a number of tests for protected speech and press rights have been developed. Courts have often struggled to connect those tests to changes in technology. Though new technology does raise new challenges, considering the original purpose and meaning of the First Amendment remains vital to the proper analysis of these rights, particularly the public's right to videorecord police.

21. See discussion infra Section III.D.3.

22. See discussion infra Sections II.A, II.B.

23. N.Y. Times Co. v. United States, 403 U.S. 713, 715 (1971) (Black, J., concurring). 


\section{A. Freedom of Speech}

\section{Original Purpose and Meaning}

The First Amendment protects the forum for discussion of ideas in the public interest. ${ }^{24}$ The Speech Clause originally meant that the First Amendment protected the right to literal in-person speech. ${ }^{25}$ Though the acts of writing or publishing ideas are often understood to be speech today, speech did not inherently include those activities at the drafting of the Constitution. ${ }^{26}$ Early writers referred to speech literally and to the press as a vehicle of speech. ${ }^{27}$ Today, the ordinary understanding of freedom of speech has come to include a wide variety of freedoms of expression, including some expression that could be called publishing, such as sharing videos and posting opinions online. ${ }^{28}$

\section{When is There Protection for Speech}

The Speech Clause protects speech itself (pure speech), conduct that precedes and is intertwined with pure speech (antecedents to speech), ${ }^{29}$ and conduct that is itself expressive (expressive conduct). ${ }^{30}$ These varying types of protected speech reflect the fact that "[c]ontrol[ing] or suppress[ing] speech may operate at different points in the speech process." 31

Pure speech includes: speaking, writing, music, dancing, painting, and tattooing among others. ${ }^{32}$ Because all of these actions are "inherently expressive," they need not include a message in order to be

\footnotetext{
24. See Alvarez, 679 F.3d at 597

25. Volokh, supra note 20, at 475.

26. Id. at 476 .

27. Id.

28. Id. at 477.

29. David Murphy, Comment, "V.I.P." Videographer Intimidation Protection: How the Government Should Protect Citizens Who Videotape the Police, 43 Seton Hall L. ReV. 319, 324 (2013) (" $[T]$ he Press Clause is interpreted to protect reasonable conduct antecedent to expression, such as legitimate means of news gathering.").

30. Ira P. Robbins, What Is the Meaning of "Like"?: The First Amendment Implications of Social-Media Expression, 7 FED. CTS. L. REV. 127, 133 (2013) (“[F]or example, the Supreme Court held that wearing armbands in protest of the Vietnam War was symbolic speech protected by the First Amendment.").

31. Citizens United v. FEC, 558 U.S. 310, 336 (2010).

32. See, e.g., Anderson v. City of Hermosa Beach, 621 F.3d 1051, 1061-62 (9th Cir. 2010); Barnes v. Glen Theatre, Inc., 501 U.S. 560, 581 (1991) (Souter, J., concurring); Murphy, supra note 29 , at 324.
} 
protected. ${ }^{33}$ If a message were required, "constitutional protection ... would never reach the unquestionably shielded painting of Jackson Pollock, music of Arnold Schöenberg, or Jabberwocky verse of Lewis Carroll.",34

Antecedents to speech include conduct preceding speech that is so "intertwined" with speech itself, it is protected alongside speech. ${ }^{35}$ The law does not, "disconnect the end product from the act of creation." 36 For example, writing is protected as an antecedent to publishing an essay and the act of tattooing is protected as an antecedent to the expression in the finished tattoo. ${ }^{37}$

Expressive conduct, or symbolic speech, refers to the freedom to express one's thoughts through conduct. The test for conduct to be expressive or symbolic speech protected by the First Amendment is: (1) "an intent to convey a particularized message," and (2) "that the message would be understood by those who viewed it." 38 Examples of expressive conduct include: "picketing, armband-wearing, flag-waving and flagburning." 39 The government is allowed more leeway to restrict expressive conduct than to restrict pure speech. ${ }^{40}$

\section{B. Freedom of the Press}

\section{Original Purpose and Meaning}

Most scholars agree that the First Amendment protection for freedom of the press was intended to protect the ability of citizens to share information in the public interest. ${ }^{41}$ The press has sometimes been called the fourth branch or an additional check on the powers of the executive, legislative, and judicial branches of government. ${ }^{42}$ Today, information in

33. See, e.g., Anderson, 621 F.3d at 1061; Barnes, 501 U.S. at 581 (Souter, J., concurring); Seth F. Kreimer, Pervasive Image Capture and the First Amendment: Memory, Discourse, and the Right to Record, 159 U. PA. L. REv. 335, 372-73 (2011) (citing Ward v. Rock Against Racism, 491 U.S. 781, 790 (1989)).

34. Hurley v. Irish-Am. Gay, Lesbian \& Bisexual Grp. of Bos, 515 U.S. 557, 569 (1995).

35. Anderson, 621 F.3d at 1062; Murphy, supra note 29, at 324.

36. Anderson, 621 F.3d at 1061-62.

37. See supra notes 31-32.

38. See Spence v. Washington, 418 U.S. 405, 410-11 (1974).

39. Fields v. City of Philadelphia, 166 F. Supp. 3d 528, 534 (E.D. Pa. 2016) (citing Texas v. Johnson, 491 U.S. 397, 404 (1989)), rev'd, 862 F.3d 353 (3d Cir. 2017).

40. Johnson, 491 U.S. at 406.

41. ACLU of Ill. v. Alvarez, 679 F.3d 583, 597 (7th Cir. 2012) (quoting Ariz. Free Enter. Club's Freedom Club PAC v. Bennett, 564 U.S. 721, 754 (2011)).

42. See Roy S. Gutterman, Note, Chilled Bananas: Why Newsgathering Demands More First 
the public interest can be shared not just through newspapers but through television, radio, blogs, forums, and social media. This means that average citizens may "check" the government the same way newspapers long have.

But even early Americans did not rely solely on newspapers for their information. Early Americans shared information through leaflets and pamphlets, including the anonymously authored Federalist Papers. ${ }^{43}$ The Constitution protected all who used the printing press to disseminate their ideas and information, not just the news organizations that society now knows as "the press." 44

"The press" did not always mean an industry of professional journalists. Near the time of the drafting of the Constitution, the "press" was defined in dictionaries as the machine called the printing press. ${ }^{45}$ Not until 1828, did Noah Webster's dictionary define "press" as both the machine and the industry. ${ }^{46}$ Webster defined the "liberty of the press" as "the unrestrained right which every citizen enjoys of publishing his thoughts and opinions....,47 The freedom of the press, therefore, protected the right of any citizen to use the machine to disseminate ideas. $^{48}$

In those early years of the country, the meaning of the words "press" and "speech" did not overlap. The freedom of the press was meant to specifically protect the freedom to print and publish, while the freedom of speech protected the freedom to literally speak. ${ }^{49}$ This separate protection for the press was important because some governments prior to the founding of the United States had specifically attempted to restrict the use of the printing press. ${ }^{50}$

In the decades after the ratification of the Constitution, state supreme courts recognized the freedom of the press as the right of every citizen to publish his or her ideas. ${ }^{51}$ Professor Eugene Volokh's survey of fifteen

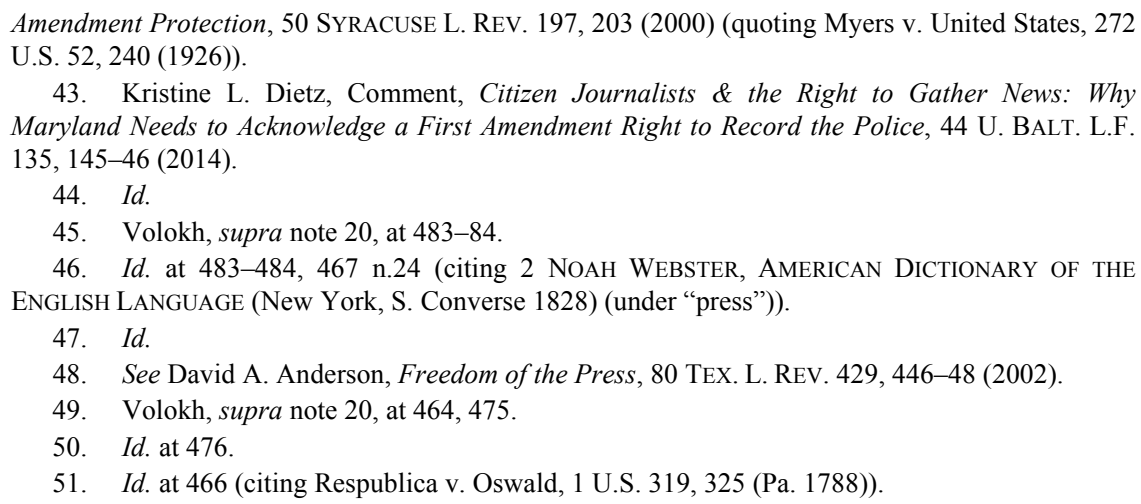


cases from 1784 to 1840 shows that the freedom of the press was used in legal arguments to protect not just journalists but the general public. ${ }^{52}$ Early cases and opinions noted that the press was not afforded extra protection beyond that afforded to the general public, which suggests that the right was not attached to the industrialized press, but to publishing in general. $^{53}$ Those judges viewed the combination of the Press and Speech Clauses as the equivalent of state constitutional provisions protecting the right of every citizen to "freely speak, write, and publish his sentiments." ${ }^{25}$ The concept of the press as professional journalists and publishers did not develop in the courts until the 1970s. ${ }^{55}$ Modern justices have also acknowledged that the freedom of the press refers to the freedom of every person to publish ideas. ${ }^{56}$

\section{When is There Protection for the "Press"?}

Freedom of the press encompasses freedom to publish as well as freedom to gather information to publish. ${ }^{57}$ Numerous courts and scholars have recognized that the right to gather information is essential to the freedom of the press. ${ }^{58}$ More than 40 years ago the Supreme Court somewhat ambiguously stated that "news gathering [sic] is not without its First Amendment protections." 59 Without protection for gathering information, the press could be prevented from functioning. Although the Supreme Court may have been ambiguous on this point, the rationale underlying the protection of newsgathering is not only clear, it is imperative. Without information, journalists cannot publish information in the public interest. ${ }^{60}$ If government were permitted to limit "the stock

52. Id. at $483-498$.

53. Id. at 498, 504 (citing Root v. King, 7 Cow. 613, 628 (N.Y. Sup. Ct. 1827)).

54. Id. at 467-68 (citations omitted).

55. Id. at 464-65.

56. Id. at 462; Citizens United v. FEC, 558 U.S. 310, 390 n.6 (2010) (Scalia, J., concurring) ("It is passing strange to interpret the phrase 'the freedom of speech, or of the press' to mean, not everyone's right to speak or publish, but rather everyone's right to speak or the institutional press's right to publish. No one thought that is what it meant."). See also discussion infra Section III.C.

57. See Houchins v. KQED, Inc., 438 U.S. 1, 9-11 (1978) ("There is an undoubted right to gather news "from any source by means within the law." (quoting Branzburg v. Hayes, 408 U.S. $665,681-82(1972)))$.

58. Id. at 11; First Nat'1 Bank of Bos. v. Bellotti, 435 U.S. 765, 783, reh'g denied, 438 U.S. 907 (1978); see also Stanley v. Georgia, 394 U.S. 557, 564 (1969); ACLU of Ill. v. Alvarez, 679 F.3d 583, 600 (7th Cir. 2012); Glik v. Cunniffe, 655 F.3d 78, 82-83 (1st Cir. 2011); CNN v. ABC, 518 F. Supp. 1238, 1244 (N.D. Ga. 1981); Kreimer, supra note 33, at 383-84.

59. Branzburg v. Hayes, 408 U.S. 665, 707 (1972).

60. Id. at 727 (Stewart, J., dissenting). 
of information from which members of the public may draw,"61 the "rights to publish, inform and exchange ideas would be moot." ${ }^{62}$ Access to information allows the discussion to occur. ${ }^{63}$ Though the contours of this right to gather news have not been distilled to a simple test, it is an acknowledged right-government may not restrain publication by restraining newsgathering.

Even for the press, however, the right to gather news has limits. The Supreme Court has refused to read the First Amendment to provide protections to the press that exceed those provided to the public. ${ }^{64}$ In Branzburg v. Hayes, the Court refused to acknowledge a journalist's privilege that would have protected journalists from being forced to reveal confidential sources. ${ }^{65}$ In Houchins v. KQED, Inc., the Court held that the news media did not have a constitutional right to access a county jail. $^{66}$ In Pell v. Procunier, the Court held that journalists had no constitutional right to interview prison inmates. ${ }^{67}$ In addition, members of the press are not immune from civil or criminal liability for newsgathering activities. ${ }^{68}$ These refusals to grant privileges to the press are based on the principle that journalists do not have a greater right of access to information than the general public. ${ }^{69}$ Rather, the freedom of the press protects every person's right to publish and the right to gather news by means available to the public. ${ }^{70}$

\section{Analysis of Citizens Who Videotape Police}

The most important question for the application of the First Amendment to citizens who videorecord police is often which test

\footnotetext{
61. Bellotti, 435 U.S. at 783.

62. Gutterman, supra note 42, at 208.

63. Id.

64. Houchins v. KQED, Inc., 438 U.S. 1, 11 (1978); see also Branzburg, 408 U.S. at 725-27 (1972) (Stewart, J., dissenting).

65. 408 U.S. at 708-09. Nevertheless, lower courts have read Justice Powell's concurrence and Justice Stewart's dissent together to hold that journalists have a qualified privilege. See Branzburg v. Hayes, Reporters' Privilege \& Circuit Courts, FIRST AMEND. CTR. (July 12, 2005), http://www.firstamendmentcenter.org/branzburg-v-hayes-reporters $\% \mathrm{E} 2 \% 80 \% 99$-privilege-circuitcourts/ ("Despite what seems to be a ruling that no reporters' privilege exists, most of the circuit courts have acknowledged a qualified privilege. There is little agreement on the extent of the privilege, however.").

66. 438 U.S. at $15-16$.

67. Pell v. Procunier, 417 U.S. 817, 834-35 (1974).

68. Erwin Chemerinsky, Protect the Press: A First Amendment Standard for Safeguarding Aggressive Newsgathering, 33 U. RicH. L. REV. 1143, 1145 (2000).

69. Houchins, 438 U.S. at 16; Pell, 417 U.S. at 833-34; Branzburg, 408 U.S. at 684-85.

70. Houchins, 438 U.S. at 9-11 (1978).
} 
applies. If a court applies the expressive conduct test under the Speech Clause, for example, and the plaintiffs fail to show intent to convey a particular message, there can be no protection. ${ }^{71}$ If, instead, a journalist videorecords police, the Speech Clause and its test for expression do not apply. ${ }^{72}$ Rather, the question, if there is one, becomes whether the journalist was engaged in newsgathering. ${ }^{73}$ Of the courts that have found First Amendment protection for videorecording police, some have recognized the activity as expressive conduct, some as a blend of Speech Clause and Press Clause protections, and others on a basis that is unclear. $^{74}$

\section{Antecedents to speech}

The first to recognize a First Amendment right to videorecord police was the Eleventh Circuit, which found First Amendment protection to film "matters of public interest" on public property. ${ }^{75}$ The court's holding rested on its earlier recognition of a right to videorecord public meetings and matters of public interest. ${ }^{76}$ In other words the holding rested on the right to gather information to enable speech. ${ }^{77}$ The court found that a right to videorecord police officers performing their duties on public property fit within the previously protected rights to gather information through access to public places and proceedings. ${ }^{78}$

The Eleventh Circuit did not state which clause of the First Amendment its holding was based on. ${ }^{79}$ But it cited to cases finding protection for members of the public in similar situations under the Speech Clause and finding protection for journalists in similar situations under the Press Clause. ${ }^{80}$ In two parentheticals, the court explained that the press and the public have similar rights to information, but it did not clearly draw a connection between the act of videorecording police and

71. See, e.g., Fields v. City of Philadelphia, 166 F. Supp. 3d 528, 535 (E.D. Pa. 2016), rev'd, 862 F.3d 353 (3d Cir. 2017).

72. Clay Calvert, The Right to Record Images of Police in Public Places: Should Intent, Viewpoint, or Journalistic Status Determine First Amendment Protection?, 64 UCLA L. REV. DISCOURSE 230, 250-51 (2016).

73. See id.

74. I have been unable to locate any cases that analyzed videorecording police as pure speech.

75. Smith v. City of Cumming, 212 F.3d 1332, 1333 (11th Cir. 2000).

76. Id.

77. $I d$.

78. $I d$.

79. Id.

80. Id. 
the Press Clause. ${ }^{81}$ Because the court's only citations to cases of citizens videorecording police were to decisions grounded in the Speech Clause and because the court made no statement directly connecting videorecording police to the Press Clause, the court is best understood to analogize the protection for the press to the protection for the public. ${ }^{82}$ For the public, gathering information precedes speaking about information and therefore under the Eleventh Circuit's analysis, videorecording is an antecedent to speech.

Most recently, in Fields v. City of Philadelphia, the Third Circuit found a right to videorecord police when it overturned a flawed Eastern District of Pennsylvania opinion. ${ }^{83}$ The Court held that there is "no practical difference between allowing police to prevent people from taking recordings and actually banning the possession or distribution of them." 84 Preventing citizens from videorecording police is unconstitutional because the First Amendment protects access to information so that it may be used in public discussion. ${ }^{85}$ Allowing the public to participate in gathering information complements the role of journalists. ${ }^{86}$

In American Civil Liberties Union of Illinois v. Alvarez the Seventh Circuit dealt with a related issue when it held that an eavesdropping statute was likely unconstitutional. ${ }^{87}$ There, the plaintiff sought an injunction, arguing that a state statute unconstitutionally prevented it from videorecording police. ${ }^{88}$ The court analyzed the act of videorecording police as an antecedent to speech, like note taking at a public event is an antecedent to publishing an article. ${ }^{89}$ Just as note taking raises First Amendment concerns, the court held that preventing the public from videorecording police raises First Amendment concerns. ${ }^{90}$ The court noted that it had "never seriously questioned that the processes of writing words on paper, painting a picture, and playing

\footnotetext{
81. Id.; see also Murphy, supra note 29 at 323 (explaining that the court "merely addressed a videographer's First Amendment rights in passing, and failed to precisely derive the source of protection from the language of the First Amendment").

82. Smith, 212 F.3d at 1333.

83. 862 F.3d 353, 362 (3d. Cir. 2017). See notes 114-120 and accompanying text discussing the district court's decision.

84. Id. at 358 .

85. Id. at $359-60$.

86. Id. at 360

87. 679 F.3d 583, 608 (7th Cir. 2012).

88. Id. at 588 .

89. Id. at $595-96$.

90. Id.
} 
an instrument are purely expressive activities entitled to full First Amendment protection." 91 Restricting a medium of expression, the court found, was tantamount to restricting the expression itself. ${ }^{92}$ Therefore, the court concluded restricting videography was restricting speech and was likely unconstitutional. ${ }^{93}$ The ACLU's clear intent to publish its recordings ${ }^{94}$ likely bolstered the court's finding of protection. If instead, there had been no clear intent to publish, the court may not have been willing to assume the act of videorecording police was an antecedent to publication.

\section{Expressive Conduct}

In Robinson v. Fetterman, the Eastern District of Pennsylvania held that the First Amendment protected the plaintiff's right to videorecord police, regardless of whether he had any reason for videorecording police. ${ }^{95}$ At first glance, this suggests that the court did not analyze Robinson's rights under the expressive conduct test because the first prong of that test requires a message to convey. Without any reason to videorecord police, Robinson could not have a message to convey and would fail the test. ${ }^{96}$

However, the court went on to list the plaintiff's reasons for videorecording police. He was recording activity that he believed to be unsafe and he had previously spoken to a state representative about his safety concerns. ${ }^{97}$ The court noted that the plaintiff had a First Amendment right to express those safety concerns through speech or conduct. ${ }^{98}$ The court also noted that videorecording police can be useful in gathering information, including evidence of certain problems or concerns, to be disseminated to the public. ${ }^{99}$ So, though the court may not have explicitly considered whether Robinson had a message to convey, intent did play a role in the court's finding of protection. If Robinson were exercising pure speech, the reasons for his speech would be irrelevant. Similarly, there would be no need for reasons or intent if

\footnotetext{
91. Id. at 596

92. $I d$. at 600 .

93. See id. at 608 (holding that plaintiff's complaint should not have been dismissed because of the strong likelihood of proving on the merits that the statute was unconstitutional). 
the conduct were so intertwined as to be considered speech. For the court's analysis to make sense, it must be that Robinson's actions were expressive conduct. The court's inclusion of the plaintiff's reasons for speaking while the court dismissed the importance of those reasons illustrates the way analysis of the right to videorecord police under the Speech Clause becomes jumbled.

In Pomykacz v. Borough of West Wildwood, the District of New Jersey focused on the requirement for an intended message when it analyzed the question of protection for a plaintiff who photographed a police officer. ${ }^{100}$ The court afforded First Amendment protection because the plaintiff showed that the photographs were linked to her political activism. ${ }^{101}$ The court specifically limited the protection to expressive or communicative photography. ${ }^{102}$ This indicates that the court viewed the videorecording as expressive conduct rather than pure speech and that the holding was limited to protection for expressive conduct.

In Pluma v. City of New York, the Southern District of New York found no clearly established protection for a "citizen journalist" who did not show intent to disseminate the video he took of Occupy Wall Street protests. $^{103}$ Because the plaintiff did not have a message to convey, his claim failed the first prong of the expressive conduct test. ${ }^{104}$ The court's specific reference to the fact that the plaintiff was a "citizen journalist" suggests that the outcome may have been different if the videographer were a professional journalist. ${ }^{105}$ In fact, another Southern District of New York judge later stated in Higginbotham v. City of New York that the Pluma analysis would not apply to a professional journalist filming a newsworthy event for broadcast. ${ }^{106}$ Higginbotham departs from Pluma in its acknowledgement that videography can be "an essential step towards an expressive activity," 107 not merely expressive conduct. This signals that the Southern District of New York might consider protection for videorecording police if the act is framed as an antecedent to speech. However, the court limited the statement to professional journalists who

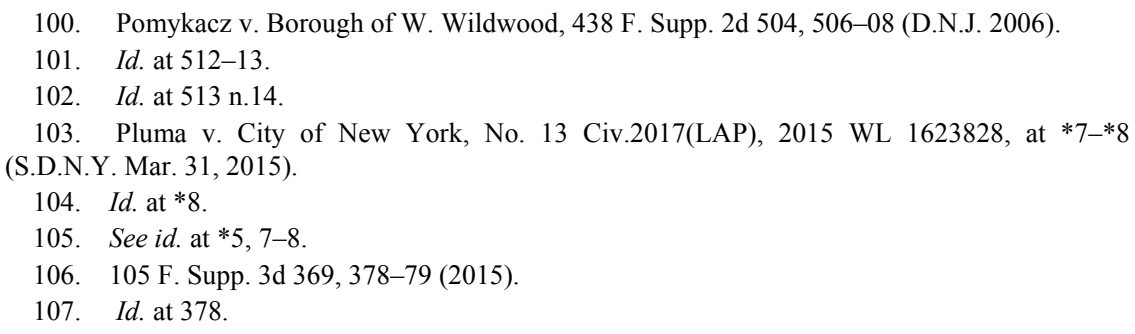


intend to publish. ${ }^{108}$ It is unclear whether the court would extend the same protection to the public.

In Gilles v. Davis, the Third Circuit said in a footnote that there "may" be a right to videorecord police performing their duties on public property, but did not answer the question. ${ }^{109}$ At the same time, the court said "photography or videography that has a communicative or expressive purpose enjoys some First Amendment protection."110 In support of this statement the court cited to three cases finding First Amendment protection for expressive conduct. ${ }^{111}$ It appears that by requiring an expressive or communicative purpose, the court means to apply the first prong of the expressive conduct test, which requires the speaker have a message to convey. ${ }^{112}$ The Court's limited analysis of the right to video record police had a significant impact on analysis of the question within the circuit.

Because Gilles' precedent was limited and unclear, five years later in Kelly v. Borough of Carlisle the Third Circuit held that a right to videorecord police was not clearly established. ${ }^{113}$ The defendant in Kelly argued that there was no clearly established "right to surreptitiously videotape a police officer without an expressive or communicative purpose." 114 In other words, he argued that the plaintiff could not satisfy the elements of the expressive conduct test. Rigid adherence to this expressive conduct framework likely slowed progress in the right to videorecord police in the circuit because it prevented courts from considering other type of speech that might apply.

The next noteworthy case, Fields v. City of Philadelphia was recently reversed by the Third Circuit, it is nevertheless worth discussion because it provides an example of the problems that may arise when courts attempt to apply the expressive conduct test to video recording police. ${ }^{115}$ In Fields, the Eastern District of Pennsylvania found no First Amendment protection for a plaintiff who took photos of a police gathering from a public sidewalk or another plaintiff who took video of police arresting a protestor. ${ }^{116}$ The court reached its conclusion by

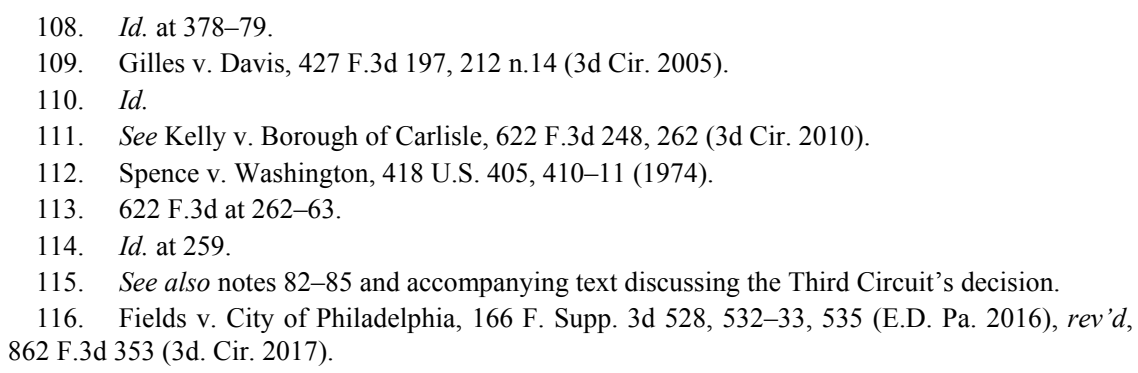


focusing on whether the plaintiffs' conduct was sufficiently expressive to be protected. ${ }^{117}$ The court however went beyond the requirement that an actor have "an intent to convey a particularized message." 118 The court required a critical message. ${ }^{119}$

This requirement of a critical message may explain why the Eastern District of Pennsylvania afforded Robinson protection when it did not afford Fields and his co-plaintiff in the consolidated action protection. In Robinson, there was evidence that the plaintiff intended to be critical and that the audience would understand that critical message. Robinson had voiced his concerns about unsafe procedures to his state representative and police were aware of his concerns because they had arrested him previously for videorecording the same activities. ${ }^{120}$ At the district court level in Fields, the plaintiffs could not show that the conduct itself was expressive, let alone critical of police. ${ }^{121}$ Therefore, this requirement for a critical message made it impossible for the plaintiffs to prevail. ${ }^{122}$ There is also an indication that the district court would have treated journalists differently. The district court specifically noted that the plaintiffs were not members of the press while analyzing the plaintiffs' expressive behavior. ${ }^{123}$ This suggests that the court may have asked different questions if the plaintiffs had been journalists. Perhaps the court would have presumed journalists intended to convey a message.

\section{The Press Clause}

In Glik v. Cunniffe, the First Circuit analyzed the public right to videorecord police through the lens of First Amendment protection for "conduct related to the gathering and dissemination of information." 124 The First Circuit did not state under which clause or type of speech it analyzed this question, ${ }^{125}$ but the court did emphasize the First Amendment purpose of allowing access to information to promote discussion of government. ${ }^{126}$ An opinion flowing from this purpose could be read under the Speech Clause, in which case the Court

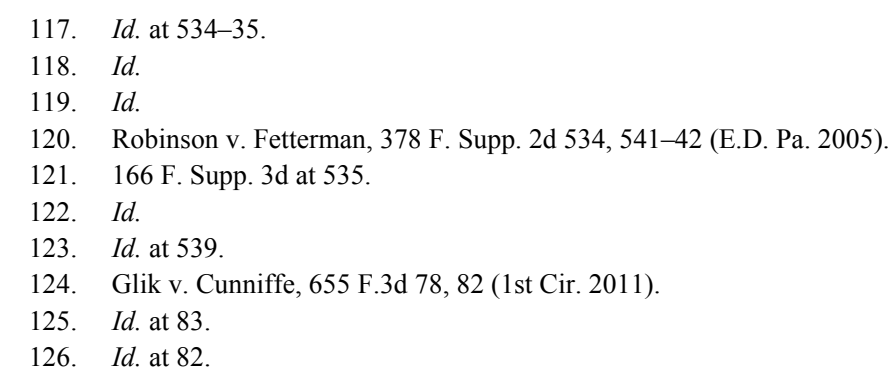


analogized videorecording police to other antecedents to speech and protected videorecording police as an antecedent to speech. On the other hand, the opinion could be read under the Press Clause, in which case the court determined that the protection for newsgathering extends to the general public as well as to the press.

A close look indicates that the court was extending Press Clause protection to the public. The court noted that the press and the public share the same rights of access to information ${ }^{127}$ and that "[t]he First Amendment right to gather news" applies to both the press and the public. ${ }^{128}$ The First Circuit's analysis indicates that its intention was to extend Press Clause protection beyond the news industry to any person gathering "news." 129 First, the court cited cases affording protection to journalists videorecording or photographing police to support protection for the public. ${ }^{130}$ Second, the court mentioned the difficulty in drawing the line between journalist and citizen when both have the technological means to gather and widely share information. ${ }^{131}$ And third, the court noted that bystanders may be just as likely to take images of current events as journalists. ${ }^{132}$ Though the analysis could be read to protect videorecording as an antecedent to speech, for the reasons listed above, it is more likely that the court was applying the Press Clause. ${ }^{133}$

In Garcia v. Montgomery County, the District of Maryland drew on Supreme Court precedent to find that the public has a right to record police officers in the performance of their duties. ${ }^{134}$ The court focused on the Supreme Court's statement in Houchins v. KQED, Inc., that "[t]here is an undoubted [First Amendment] right to gather news "from any source by means within the law." 135 The court then noted that the

127. Id. at 83-84; see also Marc Jonathan Blitz, The Right to Map (and Avoid Being Mapped): Reconceiving First Amendment Protection for Information-Gathering in the Age of Google Earth, 14 COLUM. SCI. \& TECH. L. REV. 115, 145 (2013).

128. Glik, 655 F.3d at 83-84; see also Conor M. Reardon, Note, Cell Phones, Police Recording, and the Intersection of the First and Fourth Amendments, 63 DUKE L.J. 735, 748-50 (2013).

129. See Laurent Sacharoff, Cell Phone Buffer Zones, 10 U. St. Thomas J.L. \& PuB. POL'y 94, 97 (2016) (suggesting there is First Amendment protection for an individual to videorecord police and premising "this right on the First Amendment right to gather news as part of the process of disseminating news").

130. Glik, 655 F.3d at 82 .

131. Id. at 84 .

132. Id. at $83-84$.

133. Fields v. City of Philadelphia, 166 F. Supp. 3d 528, 538 (E.D. Pa. 2016), rev'd, 862 F.3d 353 (3d Cir. 2017).

134. Garcia v. Montgomery Cty., 145 F. Supp. 3d 492, 506-08 (D. Md. 2015).

135. Id. at 506 (citing 438 U.S. 1, 11 (1978)). 
Supreme Court has found "the free discussion of governmental affairs" important to the First Amendment. ${ }^{136}$ Together, these Supreme Court cases led the court to the conclusion that First Amendment protection exists for recording government actions that may become newsworthy, whether or not they are newsworthy at the moment they are recorded. ${ }^{137}$ Here again it is unclear whether the court is relying on the Press Clause or the Speech Clause in its analysis. Like Glik, Garcia could be read as an acknowledgement that the public has rights under the Press Clause or as an analogy of public information gathering to journalist newsgathering. Because of the mention of newsworthiness and Houchins, Garcia is best understood as Press Clause protection for the public.

\section{Analysis of Journalists Under the First Amendment}

The analysis of First Amendment protection for journalists is much simpler. Because "the press" has come to mean the news industry, application of the Press Clause is all but automatic. In some instances, courts may technically require that journalists have intent to publish the videos they record before granting First Amendment protection, but in practice courts presume journalists intend to publish those videos. ${ }^{138}$

The deepest discussions of intent to publish occur in reporter's privilege cases. In those cases, some circuits have held that intent to disseminate information in the public interest is a prerequisite to the reporter's privilege. ${ }^{139}$ But analysis of intent only occurs when the person claiming the privilege is not a journalist. ${ }^{140}$ When the person claiming the privilege is a journalist, the intent requirement is never even considered or applied to the facts - it is apparently presumed to be satisfied. ${ }^{141}$

\footnotetext{
136. Id. at 507 .

137. Id.

138. ACLU of Ill. v. Alvarez, 679 F.3d 583, 598-603 (7th Cir. 2012); Fields v. City of Philadelphia, 166 F. Supp. 3d 528, 539 (E.D. Pa. 2016) (stating that "[plaintiffs] are not members of the press as support for lack of intent to share images of police"), rev'd, 862 F.3d 353 (3d Cir. 2017).

139. See e.g., Cusumano v. Microsoft Corp., 162 F.3d 708, 714 (1st Cir. 1998); In re Madden, 151 F.3d 125, 129 (3d Cir. 1998); Shoen v. Shoen, 5 F.3d 1289, 1293-94 (9th Cir. 1993); von Bulow v. von Bulow, 811 F.2d 136, 143-44 (2d Cir. 1987).

140. Cusumano, 162 F.3d at 714; In re Madden, 151 F.3d at 128-29; Shoen, 5 F.3d at 1293-94.

141. See Gonzales v. NBC, Inc., 194 F.3d 29, 34 (2d Cir. 1999) (stating that intent to publish is required but never applying the requirement to National Broadcasting Company); United States v. Cuthbertson, 630 F.2d 139, 147 (3d Cir. 1980) (finding that the goal of promoting dissemination of information in the public interest supports the reporter's privilege and granting protection under the privilege without considering whether reporter intended to publish).
} 
At the heart of these Press Clause cases is a nexus between the public interest and the act of newsgathering. ${ }^{142}$ Protection is afforded to activities that promote access to information that can be published as news. Therefore, protection is granted for keeping sources confidential, in gathering information for stories, or in videorecording police.

\section{ANALYSIS}

Building on the concepts established in Part II, this section will show that the right to videorecord police is best analyzed as an antecedent to speech under the Speech Clause or as newsgathering under the Press Clause. Next, this section will show that affording citizens who videorecord police a presumption of intent to publish best focuses the analysis and best serves the purpose of both the press and Speech Clause. Finally, this section discusses the numerous reasons the Supreme Court should address this issue at its earliest opportunity.

\section{A. Purpose and Meaning of the First Amendment}

As the Supreme Court has noted, the purpose of the First Amendment is to allow the sharing of information in the public interest. $^{143}$ In recent years, as criticism of certain police practices has grown, so has interest in how the police perform their duties. Video of police officers at work is of interest to the public because it allows the public to see how police officers perform their duties, especially when interacting with the public. ${ }^{144}$ A video record also gives individuals and the public a better ability to address situations where the police officer and a citizen tell conflicting stories about a sequence of events. This access to a third source of evidence prevents abuses of power that could occur if the government were permitted to hold a monopoly on information. ${ }^{145}$ Furthermore, protecting public videorecording of police

\footnotetext{
142. von Bulow, 811 F.2d at 143-44 ("Journalists who seek to guard information that has not been published... have been accorded the protective shroud. 'Like the compelled disclosure of confidential sources, [the compelled production of a reporter's resource materials] may substantially undercut the public policy favoring the free flow of information to the public that is the foundation of the privilege."').

143. Ariz. Free Enter. Club's Freedom Club PAC v. Bennett, 564 U.S. 721, 755 (2011); see also Volokh, supra note 20, at 524 (explaining that courts have protected non-journalists along with journalists when there is an intent to disseminate information to the public).

144. See Dietz, supra note 43, at 148.

145. Id.
} 
gives the public a better idea of whether there is a problem with police procedures and, if so, how big that problem is.

A presumption that citizens intend to publish videos of police serves the purpose of public discussion because citizens who videorecord police are likely to publish the video. An age of mass information sharing indicates that a person is unlikely to take video of a controversial topic and never share it. They may turn the video over to a news station for publication on television or the Internet. They may share the video on social media. They may show it to friends. If citizens are not protected in the initial act of videorecording police, they are prevented from all of these later publications. ${ }^{146}$ The public might then be deprived of important images, such as the citizen videography of the beating of Rodney King, the assassination of President John F. Kennedy, or the police shootings of black men today. ${ }^{147}$ It is exactly this sort of deprivation that the First Amendment was intended to prevent.

\section{B. The Best Avenues for Analyzing Videorecording of Police}

The way courts frame the analysis of First Amendment protection for videorecording police plays a major role in determining whether there is First Amendment protection. Courts should be wary of inadvertently putting the cart before the horse by focusing their analysis on one type of protected expression before determining if that type of expression suits the act of videorecording police. The right to videorecord police can be properly assessed under either the antecedent-to-speech test or the press clause analysis. Both approaches keep the court focused on the act of videorecording police in its truest sense-in which it is inextricably tied to information in the public interest. Each of the other speech analyses prove inapt.

\section{Pure Speech and Expressive Conduct}

Attempts to analyze videorecording police as pure speech are misguided because the analysis of speech is not intended to protect activity like videorecording police. Pure speech is meant to protect "inherently expressive" activity. ${ }^{148}$ The act of videorecording is not inherently expressive. It does not evoke thoughts or feelings. It is not in

\footnotetext{
146. Id. at $149-50$.

147. Id. at $146-47$.

148. Barnes v. Glen Theatre, Inc., 501 U.S. 560, 581 (1991) (Souter, J., concurring).
} 
itself alone expressive of anything. It would more aptly be called conduct than speech.

The expressive conduct analysis is even more ill-suited to analyze videorecording of police. Expressive conduct is conduct "sufficiently imbued with elements of communication to fall within the scope" of First Amendment protection. ${ }^{49}$ Conduct can only be considered expressive if it (1) carries an intent to convey a message in itself and (2) people who view the conduct would be able to understand the message. ${ }^{150}$ As some courts have noted, videorecording police is inconsistent with expressive conduct. ${ }^{151}$ People who videorecord police may have an intent to convey a message that people would understand, but that intent and message are found in the video and the plans to publish the video, not in the act of videorecording itself. When courts attempt to fit videorecording police into expressive conduct, they are likely to inadvertently favor a message of criticism because it is easier for an audience to understand a message of criticism. If police conduct in a given situation is questionable, the police and other bystanders are likely to understand that act of videorecording as critical. On the other hand, if police conduct appears generic, the audience is likely to have more trouble interpreting the message - it could be critical, it could be praise, or there could be no message whatsoever. This favoring of one message over another is itself a First Amendment violation ${ }^{152}$ and should not be permitted to play a part in the analysis of First Amendment protection.

Videorecording fails pure speech and expressive conduct tests because those tests were never meant to apply to activities like videorecording police. The antecedent to speech and newsgathering protection, on the other hand, were meant to protect precisely this type of activity.

\section{Antecedents to Speech}

The rationale for protecting antecedents to speech under the Speech Clause is that the antecedent is so intertwined with the speech itself that it is a part of the speech and therefore should be protected just as the

\footnotetext{
149. Spence v. Washington, 418 U.S. 405, 409 (1974).

150. Texas v. Johnson, 491 U.S. 397, 404 (1989) (citing Spence, 418 U.S. at 410-11).

151. See discussion supra, Section II.B.2.

152. Calvert, supra note 72 , at 247 (noting that viewpoint discrimination is "exceedingly disturbing" because it is a type of content-based discrimination that has long been held unconstitutional). See also Rosenberger v. Rector of the Univ. of Va., 515 U.S. 819, 829 (1995) ("When the government targets not subject matter, but particular views taken by speakers on a subject, the violation of the First Amendment is all the more blatant").
} 
speech is protected. ${ }^{153}$ Just as an essay cannot be published unless it is written, a video cannot be shared unless it is recorded. ${ }^{154}$ To "disconnect the end product from the act of creation" is inappropriate ${ }^{155}$ because without the freedom to record the video, the video cannot be published. This analysis properly considers the issue through the lens of the purpose to protect speech.

Some courts that use the antecedent-to-speech analysis draw an analogy to the press's right to gather news. ${ }^{156}$ This analogy is supported by the fact that the public has the same right to access information as the press. ${ }^{157}$ So just as the press is protected in gathering information for publication, the public is protected in gathering information for speech. This analysis is also proper because it considers the broader First Amendment purpose to protect the forum for discussion of issues in the public interest. ${ }^{158}$

One risk of the antecedent-to-speech approach is that it could be easy for courts to slide from that analysis into expressive conduct. Robinson v. Fetterman provides an example of this problem. The opinion appears to begin as an antecedent to speech analysis. The court mentioned that the public has a right to express concerns and that there is an important public interest in gathering information. ${ }^{159}$ The court also said that the plaintiff was not required to show any reason for videorecording police; in other words, he need not have a message to convey. ${ }^{160}$ Next the court should have considered whether the plaintiff's conduct was so intertwined with speech itself that it should be protected as speech. But instead, even though it had just stated that the reasons the plaintiff had for videorecording police were unnecessary to the discussion, ${ }^{161}$ the court went on to discuss those reasons. Because the court ignored the issues important to determining protection for antecedents to speech, but discussed the issues important to expressive conduct, the court turned an antecedent-to-speech analysis into an expressive-conduct analysis, seemingly without even realizing it was doing so.

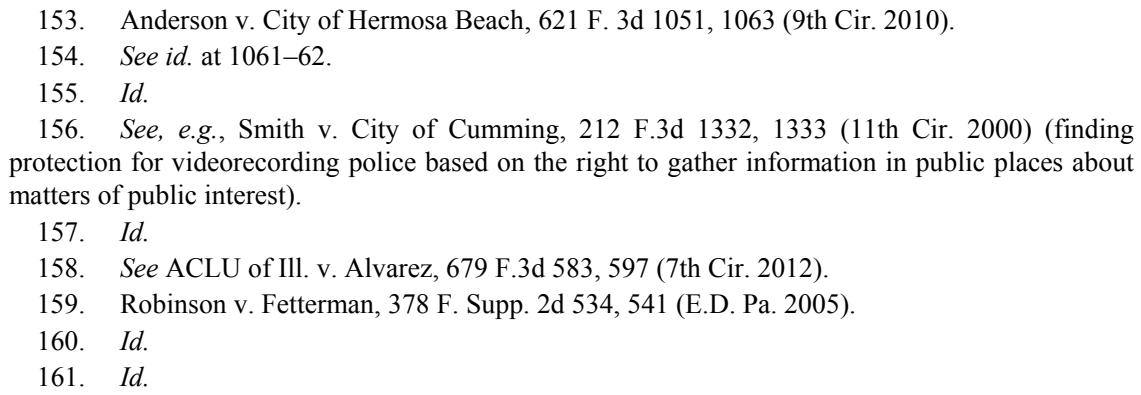


The risk of sliding into expressive conduct can be mitigated. A clear indication from the Supreme Court would make this jumbled analysis unlikely to reoccur. Additionally, as further explained infra, the risk that a court will engage in this faulty analysis is mitigated by a presumption that the public intends to publish videorecordings of police. If courts start with this presumption, it becomes clear that the case is really about antecedents to publication, not about expressive conduct.

Another risk of the antecedent-to-speech approach is that a court may require citizens to show a clear intent to publish the video. Without such an intent, the court may feel it is being asked to recognize an antecedent to non-existent future speech. Part of the reason for requiring a citizen to prove intent is overemphasis on the idea that the protected activity is an "antecedent" to speech. The idea behind the protection for antecedents to speech is that actions leading up to speech are protected in order to preserve the speech itself. Overemphasis on the word "antecedent," instead of the rationale that the action is intertwined with speech leads to the error of requiring intent to publish when courts should be protecting the ability to publish. Courts should take care to consider the meaning of the word "antecedent" within the framework of protecting the forum for discussion of matters in the public interest.

\section{The Press Clause}

Courts could also effectively analyze the First Amendment protection for videorecording police as a protected activity under the Press Clause. ${ }^{162}$ The Press Clause protects the right to gather information because information is essential to the freedom to publish. ${ }^{163}$ The Press Clause therefore protects publication by protecting the right to gather information.

When the industrialized press is stopped from lawfully gathering information, a First Amendment violation occurs. ${ }^{164}$ There is no need for a particular message to be conveyed by the gathering of information and there is no need for the act of gathering information to be intrinsically expressive. ${ }^{165}$ Instead, the information gathering is protected in order to

\footnotetext{
162. See discussion supra Section II.C.3.

163. Houchins v. KQED, Inc., 438 U.S. 1 , 11 (1978).

164. In re Express-News Corp., 695 F.2d 807, 810 (5th Cir. 1982) (finding a federal district court's order prohibiting a newspaper reporter from interviewing discharged jurors violated the reporter's First Amendment rights); United States v. Sherman, 581 F.2d 1358, 1361 (9th Cir. 1978) (same).

165. In re Express-News Corp., 695 F.2d at 810; Sherman, 581 F.2d at 1361.
} 
protect publication. Because the Press Clause was intended to protect all publication, rather from journalists or the public, it is appropriate to analyze videorecording police under the Press Clause.

\section{The Presumption and Its Application Under Each Clause}

The presumption is necessary to ensure that the press is not favored over the public. Even if videorecording police is properly analyzed as an antecedent to speech or as newsgathering, First Amendment protection may not be afforded because of the difference in the way courts treat the press and the public. When citizens are required to show intent but journalists are not, the bar for protection of citizens who videorecord police is raised above the bar required for the protection of professional journalists who videorecord police. ${ }^{166}$ Just as it is reasonable to presume that journalists intend to publish their stories, it is reasonable to presume that citizens who videorecord police intend to publish those videos.

A presumption of intent to publish is reasonable because police activities are currently of heightened interest to the public. ${ }^{167}$ If a citizen sees police activity and records it, he is likely to share it because he is likely aware of the popularity of previous recordings. Furthermore, he need not share the video on television for the act of sharing to properly be called publishing because sharing within a small circle is publishing. ${ }^{168}$ Thus, sharing the video with friends on social media is publishing.

166. See ACLU of Ill. v. Alvarez, 679 F.3d 583, 598-603 (7th Cir. 2012); Grosjean v. Am. Press Co., 297 U.S. 233, 249, 249-51 (1936).

167. See, e.g., Barbara Armacost, The Organizational Reasons Police Departments Don't Change, HARV. BuS. REV. (Aug. 19, 2016), https://hbr.org/2016/08/the-organizational-reasonspolice-departments-dont-change; Meghan Keneally, Law Enforcement Analysts Call for Changes to Police Training After Recent Incidents, ABC News (May 5, 2015, 6:23 PM), http://abcnews.go.com/News/law-enforcement-analysts-call-police-training-recent-

incidents/story?id=30827523; Greg Meyer, A Revolution in Use-of-Force Policy and Training?, POLICE MAG. (Mar. 7, 2016), http://www.policemag.com/channel/patrol/articles/2016/03/arevolution-in-use-of-force-policy-and-training.aspx; Petition: We Demand National Change to Protect Citizens and Communities from Police Violence and Misconduct, CHANGE.ORG, https://www.change.org/p/u-s-senate-we-demand-national-change-to-protect-citizens-andcommunities-from-police-violence-and-misconduct (last visited Oct. 2, 2017).

168. Kreimer, supra note 33, at 376-77. One might argue based on the logic of Dun \& Bradstreet, Inc. v. Greenmoss Builders, Inc., that publications to small groups are less protected under the First Amendment. See 472 U.S. 749, 762 (1985). But that argument fails because the Dun court made clear that matters of public concern occupy the "highest rung of the hierarchy of First Amendment values." Id. at 759 (internal citations omitted). With this in mind, it becomes clear that the Court's focus was not on the number of people who received the information in question, but on whether the information was a matter of public concern. In that case, that only five people received the information helped the court determine whether it was a matter of public concern, but the number of recipients was not among the factors the court listed in its test. Id. at 761-62. In cases of 
There may have once been an argument for a slight difference in press and public protection, but it does not exist today. Nearly 40 years ago, Justice Stewart argued that the "concept of equal access must be accorded more flexibility in order to accommodate the practical distinctions between the press and the general public."169 But 40 years ago smart phones were decades from being invented. At that time, there were major differences in journalists' and the public's ability to capture and disseminate information. Because the purpose of journalists is to be agents of the public who gather and share information with the public, ${ }^{170}$ the public interest was served by granting journalists greater flexibility than the public.

Today, information in the public interest is just as likely to originate with an average citizen and her cell phone as it is a professional journalist. There is no need to afford greater flexibility to the press as a representative of the public when members of the public can represent their interests themselves. ${ }^{171}$ As news organizations cut staff and spread efforts between paper and electronic media, citizen journalists play an important role in the free flow of information. ${ }^{172}$

The presumption of intent to publish focuses the analysis of the right to videorecord police and could keep courts from straying into considering types of speech that are ill-suited to the issue. When the public is presumed to intend to publish videos of police, it becomes clear that the act of videorecording police is an effort to gather information. It then becomes clear that information is inextricably intertwined with the ability to publish. It also becomes clear that pure speech is not the proper avenue for analyzing this issue because intent is not at issue in pure speech. The presumption would also lead courts closer to finding that the expressive conduct test is satisfied. With an intent to publish, an intent to convey a particular message is only a step or two away. The presumption would help courts and litigants focus on the correct intent question and thereby recognize that it is the end product, not the act of videorecording that is meant to be expressive.

\footnotetext{
citizens videorecording police the public concern is clear today because of the intense societal interest in the issue. Questions about how many people might see a video of a police officer are irrelevant and merely obscure the point that police activities are of public concern.

169. Houchins v. KQED, Inc., 438 U.S. 1, 16 (1978) (Stewart, J., concurring).

170. Herbert v. Lando, 441 U.S. 153, 189 (1979) (Brennan, J., dissenting in part).

171. Steven A. Lautt, Note, Sunlight Is Still the Best Disinfectant: The Case for a First Amendment Right to Record the Police, 51 WASHBURN L.J. 349, 372-73 (2012).

172. Kreimer, supra note 33, at 349-50 (noting that citizen's videorecordings have played an important role in informing the public in many recent events, from recording police brutality to providing immediate video from the 2004 Asian tsunami and the 2005 London Tube bombings).
} 
The presumption should be rebuttable to ensure that First Amendment protection is appropriate. A videographer would be assumed to have intent to publish videorecordings of police unless or until the opposing party showed that the videographer did not intend to publish the videorecordings. A model rebuttable presumption already exists in the First Amendment context in the presumption that criminal trials are open to the public. ${ }^{173}$ This presumption may be overcome with "findings specific enough that a reviewing court can determine whether" the presumption was properly overcome. ${ }^{174}$ Similarly, the rebuttable presumption of intent to publish videos of police could be overcome by specific findings that show the videographer did not intend to publish the video. If, for instance, the videographer herself said at the time of the videography that she intended to keep the video for herself alone, the opposing party would be able to use that statement, absent other contrary evidence, to successfully rebut the presumption.

At its next opportunity, the Supreme Court should hear a case on the First Amendment right to videorecord police. The Court should clarify this area of the law by analyzing the activity as an antecedent to speech or as newsgathering and by adopting a rebuttable presumption that citizens intend to publish videos of police.

\section{Why the Status Quo Must Change}

Some might argue that the Supreme Court need not address this issue because the circuit courts have found protection for the right to videorecord police. On the contrary, the Court should address this issue because the circuits are struggling to properly characterize and analyze the act of videorecording police. Many lower courts have analyzed the issue in ways that defy the Court's precedent holding that the press and public should be treated equally. Some consider facts that are not relevant to the stated type of expression. The cases analyzed in Part II.C illustrate the current confusion in this area of law. The courts vary widely in their approaches to the issue. Though the First, Third, Fifth, and Eleventh circuits have acknowledged a right to videorecord police, the basis of their findings is not uniform. The First Circuit found a right to videorecord police based on the right to gather information. ${ }^{175}$ The Seventh Circuit held that a statute interfering with the right to

\footnotetext{
173. Press-Enterprise Co. v. Superior Court of Cal., 464 U.S. 501, 510 (1984).

174. Id.

175. Glik v. Cunniffe, 655 F.3d 78, 82 (1st Cir. 2011).
} 
videorecord police implicated the same concerns as interfering with traditional antecedents to speech. ${ }^{176}$ The Eleventh Circuit based its holding on recognizing videorecording police as an antecedent to speech, similar to the way newsgathering could be seen as an antecedent to publication. ${ }^{177}$ This variation leaves lower courts, particularly in circuits that have not addressed the question, without a clear path to follow.

A uniform framework would better serve courts, police officers, and the public by providing clear rules and expectations. This framework should respect precedent, avoid distinctions between the press and the public, and protect the public interest.

\section{Respecting Supreme Court Precedent}

A long line of Supreme Court cases hold that journalists are not afforded greater rights to information than the public. ${ }^{178}$ "[T] Amendment does not guarantee the press a constitutional right of special access to information not available to the public generally." 179 Courts violate this principle of equal treatment when they presume journalists intend to publish their videos but fail to presume the same intent for citizens.

In its decisions, the Supreme Court typically considers the purpose of the First Amendment. That purpose supports equal treatment. Many Supreme Court decisions note that the First Amendment was intended to "protect the free discussion of governmental affairs." 180 The press may contribute to the discussion of government affairs on its own, but protection for a public right to videorecord police increases the amount of information available for public discussion. Equal treatment therefore aligns with the purpose of the First Amendment.

\footnotetext{
176. ACLU of Ill. v. Alvarez, 679 F.3d 583, 595-96 (7th Cir. 2012).

177. See supra notes $72-79$ and accompanying text.

178. See Volokh supra note 20, at 505-21 (discussing in detail the line of cases). See, e.g., Pell v. Procunier, 417 U.S. 817, 833-34 (1974) (holding that "newsmen have no constitutional right of access to prisons or their inmates beyond that afforded the general public"); Branzburg v. Hayes, 408 U.S. 665, 684-85 (1972) ("It has generally been held that the First Amendment does not guarantee the press a constitutional right of special access to information not available to the public generally."); AP v. NLRB, 301 U.S. 103, 132-33 (1937) (holding that the press has no immunity from generally applicable laws).

179. Pell, 417 U.S. at 833 (quoting Branzburg, 408 U.S. at 684-85).

180. Globe Newspaper Co. v. Superior Court for Cty. of Norfolk, 457 U.S. 596, 604-05 (1982) (citing Mills v. Alabama, 384 U.S. 214, 218 (1966)).
} 
2. The Problem with Defining the Press

Without a clear framework, unequal treatment of journalists and citizens is likely to continue and with that unequal treatment comes the difficult question of who is a journalist for the purpose of First Amendment protections. Basing a definition for the press on a person's status as a journalist realizes one of the fears that prompted the creation of the Press Clause in the first place. ${ }^{181}$ Defining the press is likely to lead to an attempt to distinguish between types of content that are "newsworthy" and types that are not. It might also lead to distinguishing the press based on ownership of the means of publication. Both these methods of distinguishing press and citizens are contrary to the Court's precedent. $^{182}$

Law student Camille Higham argues persuasively that instead of defining press by professional standards, the press should be defined by activity as "any person who engages in newsgathering." "183 That way anyone gathering news would be protected as a member of the press, whether that person is a part of the news industry or not. ${ }^{184}$ While this approach does broaden the protection, it does not go far enough because it could be interpreted to require defining "news," and therefore could lead to content-based qualifications for the classification of news. If protection were only afforded to those gathering what is deemed "real news," the result would be discrimination on the basis of content, which is unconstitutional. ${ }^{185}$ This concern is heightened in the wake of politically charged claims of "fake news.","86

Some have argued that the press should be treated differently from ordinary citizens because ordinary citizens may not hold themselves to the same standards as professional journalists. ${ }^{187}$ But this concern is a red herring because both members of the press and ordinary citizens are held accountable for breaking the law, whether they are engaged in

181. Camille Anjes Higham, Mediagathering vs. Newsgathering: Giving the Freedom of the Press Clause Due Recognition, 13 Fla. CoAStal L. ReV. 417, 444-45 (2012).

182. First Nat'l Bank of Bos. v. Bellotti, 435 U.S. 765, 799 (1978) (Burger, J., concurring).

183. Higham, supra note 181, at 444.

184. Id. at 445 .

185. Calvert, supra note 72 , at 247.

186. Michael Barthel et al., Many Americans Believe Fake News Is Sowing Confusion, PEW RES. CTR. (Dec. 15, 2016), http://www.journalism.org/2016/12/15/many-americans-believe-fakenews-is-sowing-confusion/.

187. Linda L. Berger, Shielding the Unmedia: Using the Process of Journalism to Protect the Journalist's Privilege in an Infinite Universe of Publication, 39 Hous. L. REv. 1371, 1376 (2003). 
gathering news or not. ${ }^{188}$ Recognizing First Amendment protection for citizens who videorecord police does not give those citizens the right to break into the police department and hide a camera or interfere with a police investigation any more than the same protection would allow journalists to do so. Case law is clear that the protection of the First Amendment does not shield those protected from generally applicable laws. ${ }^{189}$ This concern about professionalism does not outweigh the public policy considerations favoring equal treatment.

\section{Public Policy Implications}

First Amendment protection for videorecording police would serve the current public interest. Early writers believed it was important to be aware of the government's actions in order to develop opinions about those actions and vote accordingly. ${ }^{190}$ "[T] e enable every citizen at any time to bring the government and any person in authority to the bar of public opinion by any just criticism upon their conduct in the exercise of the authority which the people have conferred upon them" was the purpose of the freedom of speech and press. ${ }^{191}$ Over the last twenty years, public confidence in police actions has decreased. ${ }^{192}$ The last few years especially have seen increased criticism of police and calls for changes in training. ${ }^{193}$ Videos of police conduct inform this discussion. ${ }^{194}$ They allow citizens and officials alike to discuss police conduct in real world situations. ${ }^{195}$ These videos also provide valuable evidence, which could benefit the police's ability to charge citizens with crimes, the public's ability to protect their rights and the police's ability

188. Cohen v. Cowles Media Co., 501 U.S. 663, 669 (1991); Chemerinsky, supra note 68, at 1145 .

189. Cohen, 501 U.S. at 669 (noting a "well-established line of decisions holding that generally applicable laws do not offend the First Amendment simply because their enforcement against the press has incidental effects on its ability to gather and report the news").

190. ACLU of Ill. v. Alvarez, 679 F.3d 583, 599 (7th Cir. 2012).

191. Id. at 600 (quoting ThOMAs M. CoOley, A Treatise ON THE ConstitutionaL LiMITATIONS 4222 (1868)) (emphasis omitted).

192. Dietz, supra note 43, at 148.

193. Kevin Johnson, In Face of Criticism, Police Officials Preaching De-escalation Tactics, USA TODAY (Oct. 7, 2015, 1:20 PM), http://www.usatoday.com/story/news/nation/2015/10/07/ police-encounters-violent-baltimore-ferguson/72636622/; Ray Sanchez, Attacks Leave Police Feeling Under Siege, CNN (Sept. 4, 2015, 2:53 PM), http://www.cnn.com/2015/09/04/us/us-policefeel-under-siege/; Seth Stoughton et al., Why Police Need Constructive Criticism (Dec. 23, 2015), http://www.theatlantic.com/politics/archive/2015/12/officer-porter-mistrial-police-culture/421656/.

194. Dietz, supra note 43, at 148.

195. Murphy, supra note 29, at 351. 
to defend their actions. ${ }^{196}$ Protecting the efforts of citizens and the press alike to videorecord police officers "preserve[s] and facilitate[s] modern flows of quality information."197

Public videorecordings of police also serve the First Amendment purpose of providing a fourth check on the powers of government. ${ }^{198}$ Journalists simply cannot be in as many locations at once as the rest of the public can. Additionally, the news media's ability to gather news is challenged by decreasing resources in the face of "pressure from online competition." "Th9 "The press" has shrunk in response to changes in technology and the economy. ${ }^{200}$ Because modern journalists face shrinking resources, they are ever more likely to rely on the contributions of citizens to complete their coverage. ${ }^{201}$ The public should be allowed to step in to assist the press in its function as the fourth check on the powers of the government.

Without the right to videorecord police, complaints about police conduct and procedure become a "he said, she said" guessing game where the police have the upper hand. First, juries and judges may be more likely to believe police officers than private citizens. ${ }^{202}$ Second, without a public right to videorecord police, the police have the ability to control whether interactions are recorded. ${ }^{203}$ The police can choose to use their dash cams or body cams. Several studies, including one by the Department of Justice, ${ }^{204}$ have found that police officers are inconsistent in their use of cameras, tamper with cameras, and fail to turn cameras on when they use force. ${ }^{205}$ Even when police do use their cameras to record interactions, the fact that police recordings are the only record poses a

196. Id.

197. Barry P. McDonald, The First Amendment and the Free Flow of Information: Towards a Realistic Right to Gather Information in the Information Age, 65 OHIO ST. L.J. 249, 257 (2004).

198. See supra Section II.A.1.

199. Kreimer, supra note 33, at 349-50.

200. Amy Mitchell et al., State of the News Media 2016 4-6, Pew Res. Ctr. (Jun. 15, 2016), http://www.journalism.org/2016/06/15/state-of-the-news-media-2016/.

201. Lautt, supra note 171, at 373.

202. See Ben Casselman, It's Incredibly Rare For A Grand Jury To Do What Ferguson's Just Did, FiveThiRTyEight (Nov. 24, 2014, 9:30 PM), https://fivethirtyeight.com/datalab/fergusonmichael-brown-indictment-darren-wilson/; Earl Ofari Hutchinson, Juror Bias the Biggest Barrier to Indicting Wilson and Cops That Kill, Huffington Post (Nov. 21, 2014, 10:52 AM), http://www.huffingtonpost.com/earl-ofari-hutchinson/juror-bias-the-biggest-ba_b_6196026.html.

203. Jocelyn Simonson, Beyond Body Cameras: Defending a Robust Right to Record the Police, 104 GEO. L.J. 1559, 1566 (2016).

204. See Letter of Jocelyn Samuels, Acting Assistant Att'y Gen., D.N.M., to the Hon. Richard J. Berry, Mayor of the City of Albuquerque, N.M. (Apr. 10, 2014), http://www.justice.gov/sites/ default/files/crt/legacy/2014/04/10/apd_findings_4-10-14.pdf.

205. Simonson, supra note 203, at 1567. 
problem for the interests of justice. People are more likely to sympathize with the perspective of the videographer than the perspective of the opposite party in an interaction. ${ }^{206}$ Therefore a jury, which may already be more likely to believe police, is put in the position of sympathizing with the police. This imbalance in a matter of public interest is precisely the type of problem the First Amendment was intended to protect against.

\section{E. Constitutionally Permissible Restrictions on the Right to Videorecord Police}

Though the Supreme Court should act to clarify this area of law and recognize protection for citizens who videorecord police, this does not mean that the Court should recognize the right without limits. All First Amendment rights are subject to some restrictions:

"[E]ven in a public forum the government may impose reasonable restrictions on the time, place, or manner of protected speech, provided the restrictions 'are justified without reference to the content of the regulated speech, that they are narrowly tailored to serve a significant governmental interest, and that they leave open ample alternative channels for communication of the information." "207

The First Circuit acknowledged that reasonable time, place and manner restrictions may be placed on citizens videorecording police. ${ }^{208}$ In a later case, the court provided examples of indirect and direct restrictions that would be reasonable. ${ }^{209}$ The court held it would be reasonable for an officer to order bystanders to disperse because of safety concerns, even though that order would indirectly affect the public's ability to record police. ${ }^{210}$ It would also be reasonable for an officer to directly order a person to stop videotaping if the officer reasonably believed the videotaping was interfering with his work. ${ }^{211}$ But the reasonableness of the officer's belief is analyzed from the perspective that officers must endure the burdens of citizens exercising their constitutional rights. ${ }^{212}$ Similarly, the Seventh Circuit has held that officers may not order a person away "because he is recording, [but] may

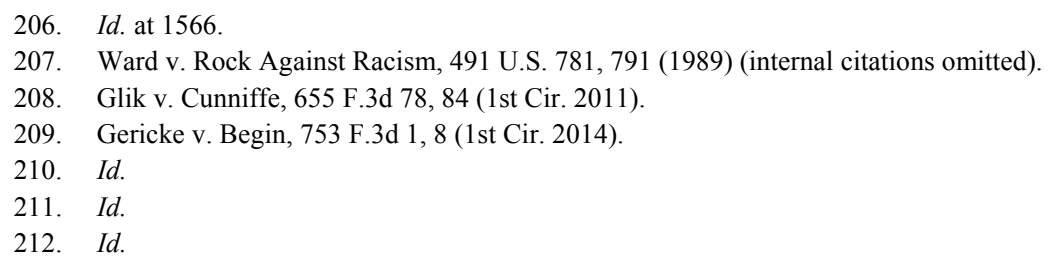


order bystanders to disperse for reasons related to public safety and order and other legitimate law-enforcement needs." 213

The Supreme Court should take a similar approach. The Bill of Rights is a balancing act of private freedoms and government interests. While constitutional freedoms are essential to the American way of life, it is also essential that government officials are able to do their jobs. The First and Seventh Circuits have sensibly balanced these interests by recognizing that in some situations the safety and needs of the public are better served by stopping the public from recording. These situations are few and should not be the driving force behind the rule. If the Court is faced with a case in which it was reasonable to limit a citizen's ability to videorecord police, the Court should frame that reasonable limit as an exception to the rule that the First Amendment protects the right to videorecord police.

\section{CONCLUSION}

The purpose of the First Amendment is well known and universally accepted - the framers wanted to protect the forum for discussion of matters in the public interest and provide a check on government abuses. Both the speech and press clause protect the right to videorecord police. The speech clause protects antecedents to speech because they are intertwined with the ability to speak. Historical analysis, coupled with application of the First Amendment's general purpose, shows that the Press Clause protects not only journalists, but all who publish ideas. In accordance with the First Amendment, protection must be given to all who videorecord police.

The Supreme Court has developed tests to protect the various types of action that the Speech and Press Clauses protect. If applied inappropriately, these tests can deny the protections they were meant to safeguard. The debate about the right to videorecord police is a perfect example of this problem. Confusion about which test to apply when citizens videorecord police has led to confusion about whether the First Amendment protects a right to videotape police at all.

Courts can and should rigorously protect the public's right to videorecord police by adopting a rule that presumes the public intends to publish and analyzes the issue as an antecedent to speech under the speech clause or as newsgathering under the press clause. The right to videorecord police should not be granted just to members of the

213. ACLU of Ill. v. Alvarez, 679 F.3d 583, 607 (7th Cir. 2012). 
industrialized press, but to anyone who might happen upon a questionable police encounter, just as Feidin Santana did. ${ }^{214}$ Affording a presumption of intent to publish will protect the ability of passersby to capture important events and further important discussions. As society wrestles with how to respond to police shootings, video of the event can only aid in that discussion and therefore serve the purpose of the First Amendment.

214. See supra Part I. 